


\section{Online folyóirat}

Szerkesztette: VÁGÁNY Judit Bernadett, PhD - FENYVESI Éva, PhD

Borító: FLOW PR

Kiadja: Budapesti Gazdasági Egyetem, Kereskedelmi, Vendéglátóipari és Idegenforgalmi Kar, Közgazdasági és Üzleti Tudományok Tanszék

Felelős kiadó: FENYVESI Éva, PhD

a Közgazdasági és Üzleti Tudományok Tanszék vezetője

ISSN 2630-886X

2020. 


\title{
A TERÜLETI TŐKE IDENTITÁS FAKTORÁNAK ERŐSÍTÉSE A SPORTOLÓI IDENTITÁS ÁLTAL
}

\author{
STRENGTHENING THE FACTOR OF REGIONAL \\ CAPITAL IDENTITY BY THE ATHLETES IDENTITY
}

FARAGÓ Beatrix - KONCZOSNÉ SZOMBATHELYI Márta

Kulcsszavak: identitás, társadalmi tókee, kultúra, sportoló, regionalitás

Keywords: identity, social capital, culture, atbletes, regionalism

JEL kód: $M 14$ 


\section{ÖSSZEFOGLALÁS}

Az identitás és a sport viszonyának egyik megnyilvánulása, amikor a sport a közösségi életet erösiti, a közösség pedig aktiv tagja és támogatója a sportnak. A nemzeti, illetve területi identitás kulturális örökeség. Ebben az aspektusban a sporttal kapcsolatos identitás értelmezhetö a társadalmi kultúra részeként. A tanulmány bemutatja a sport és a lokális identitás összefüggéseit, valamint ezek hatását a társadalmi tôkére. Kutatásunk célja a sportolói identitás felmérése és annak hatásának vizsgálata egy terület társadalmi tókéjére. Kérdésként jelenik meg, hogy a sportba való integráció identitássá válik-e; illetve, hogy milyen mértékeben maradnának/ maradtak a sportban, illetve az adott régióban a sportolói karrierjük után a megkérdezettek? Viqsgáljuk, hogy a sportolók identitása milyen hatással van az oktatási és a gazdasági környezetre, hiszen a képzés és a munkaerö-piac meghatározó szegmensét képezik. Az identitások sporthoz viszonyitott attitüdjeiben megmutatkoznak azok a tökeelemek, amelyek a régió fejlódésében, versenyképességében növeli a hatékonyságot. Az identitás mintázatok által bemutatásra kerül a sportolói, regionális, nemzeti identitás meghatározása, azok hatásai egymásra. Az empirikus kutatás megmutatja, hogy a sportolói identitás megjelenik a sportolóknál, annak hatása a területi tökére a terïleti-, társadalmi-, humán tóke elemeként érvényesül. A kutatás eredménye a versenyképesség fejlesztő mechanizmusának elemeiben nyújt üj irányt, amely a sportolói szegmens tökeértékét mutatja be.

\section{SUMMARY}

One of the manifestations of the relationship between identity and sport is when sport strengthens community life and the community is an active member and supporter of the sport. National or regional identity is a cultural heritage. In this aspect, sports identity can be interpreted as a part of social culture. The study presents the relationship between sport and local identity and their impact on social capital. Our research aims to assess the athlete's identity and examine its impact on the social capital of an area. The question is whether integration into sport becomes an identity; and what extent would the respondents stay in / stay in sports or their region after their sports career? We examine the impact of athletes' identities on the educational and economic environment, as they form a decisive segment of training and the labor market. The attitudes of identities about sport are reflected in the capital elements that appear in the development and competitiveness of the region. Identity patterns illustrate the definition of athletes, regional, national identities and their effects on each other. Empirical research shows that the athlete's identity appears at the athletes, its effect on the territorial capital is valid as a component of territorial, social and human capital. The result of the research is a new direction in the elements of the competitiveness development mechanism, which shows the capital value of the athlete segment.

\section{BEVEZETÉS}

A sport és a területiség összefüggése, mint gazdaságélénkítő tényezô, a versenyképességben egyre erőteljesebb szerepet kap. A sport globalizáltsága a gazdaságban való megjelenése a területi versenyképességre is pozitív hatással bír. A sport hatásmechanizmusai komplexen érvényesülnek, amelyben a gazdasági-, és társadalmi hatékonysága egyaránt megjelenik. A nemzetközi és a nemzeti gazdasági versenyképességben is lényeges az innovatív területek kihasználása, amelyben a sport 
kiemelt szerepet képvisel. A területi és sportolói identitás egymásra való hatása a fejlődés innovatív kitörési pontját képviseli. A témakör jelentősége ebben a tekintetben újszerű és a jelenlegi társadalmi, gazdasági folyamatokban a fejlesztő mechanizmusok tényezőjeként jelenik meg.

A nemzeti identitás, amelyen a nemzetet, mint közösséget értjük, a kulturális örökségen alapul és az államszervezet határolja be. A kulturális örökség magában foglalja a falu, a régió vagy akár Európa közös kulturális örökségét. Ebben a közegben a sport identitásformáló örökségként jelenik meg, amelynek jellemző formája intézményes, egyegy eseményhez köthető (Dóczi, 2008). A nemzeti identitás és a sport kapcsolatának egyik formájában, amelyben az identitás az integráció szempontjából értelmezhető, a sport a közösségi életet erôsíti (Eichberg, 2003). A tanulmány témaköre a sport és a regionális identitás kölcsönhatása, valamint ezek hatása a társadalmi tőkére, amely a munkaerő-piaci humánerőforrásként válik versenyképességi tényezővé. Az identitás és a sport kapcsolatának egyik formája, amikor a sport a közösségi életet erősíti, a közösség pedig aktív tagja és támogatója a sportnak. A nemzeti, illetve területi (település, régió vagy akár Európa) identitás kulturális örökség. Ebben az aspektusban a sporttal kapcsolatos identitás értelmezhetô a társadalmi kultúra részeként.

A sportolói identitás (a sportolók sporthoz fűződő viszonya) a pályaválasztásban meghatározó terület, hiszen a sportolói attitűd megjelenik a pályaorientációban is, amelyre hatással van a saját képzettség és a szülők képzettsége is. A sportfejlesztési programok hatással vannak a sportolók karrierépítésére. Lényeges szempont, hogy a sportfejlesztési programokat és a tanulást, a nevelést fejlesztő programokat párhuzamosan valósítsuk meg. A sportstratégiai cél elérését, amely alapja a sportoló nemzet kialakításának, csak képzett emberek segítségével lehet elérni (Gősi, 2018). Az élsportoló karrierútja kettős, egyrészt a sportkarrier, másrészről a civil élet karrierépítése szükséges számára. A sportkarrier a korai életszakaszra jellemző, míg a civil karrier az átlaghoz képest időben hátrébb csúszik, így a sportoló a munkaerőpiacon hátrányban indul (Gősi, Sallói, 2017). Az élsportoló munkaerőpiaci foglalkoztatásánál egyik kiemelt terület az atipikus foglalkoztatás, amely kedvezően rugalmasan idomul a sportolói pályához és abban való szocializációhoz, így a sportoló kiteljesedhet a munka világában is. Az atipikus foglalkoztatás növeli a szervezetek alkalmazkodó képességét, a vállalati versenyképességet (Gôsi, 2017). A sportszövetségek állami támogatásoktól való függősége (Gősi, Bukta, 2019) bizonytalanná teszi a sportolói életút véghezvitelét, ezért lényeges a vállalati szféra felé való törekvés a sport területén is.

A tanulmány célja a sportolói identitás felmérése és annak hatásának vizsgálata egy terület humán tőkéjére. A tanulmányunk egyik kérdése, hogy milyen mértékben maradnának/maradtak a sport területén, illetve az adott régióban a sportolók a sportolói karrierjük után? 
Vizsgáljuk, hogy a sportolók identitása milyen hatással van az oktatási és a gazdasági környezetre, hiszen a képzés és a munkaerőpiac meghatározó szegmensét képezik. Mindezek alapján az alábbi hipotéziseket fogalmaztuk meg, az identitások megjelenési formái, azok egymásra hatása, érvényesülése tekintetében:

1. hipotézis: A sportolók a sportolói pályafutásukat követően a sporthoz jelentősen kötődnek, ezzel a sport funkcióinak társadalmi-, gazdasági hatásait lokális szinten erősítik. 2. hipotézis: A sportolók a sportolói pályafutásukat követően a sportban szeretnének maradni, amely a társadalmi tőke részeként jelenik meg.

3. hipotézis: A sportolók tanulmányaikat sport területén szeretnék végezni, amely a területi tőke növeléséhez járul hozzá.

A tanulmányunk első részében bemutatásra kerül az elméleti háttér, amely az identitás mintázatokat mutatja be a sport kapcsolatában (sportolói identitás, területi identitás), majd a szakirodalmi elemzésben kitérünk a sportoló szerepére a társadalmi tôkében, a humán tôke elemeként. Ez összefügg azzal, hogy a vállalatok regionális beágyazódását erősíti a sporthoz, a sportolókhoz való kötődés. Ennek számos formája létezik, a sport támogatása, a sportolói szponzoráció, mint imázsépítő, regionális identitást erősítő tényező. A tanulmány második felében a primer kutatás eredményei kerülnek bemutatásra, amely a sportolói identitás vizsgálatát tűzte ki célul. A kérdőíves kutatás a sportolói oldalról mutatja be a sporthoz való kötődést, míg a szekunder kutatás a sportolói identitás területiségre való hatását elemzi.

\section{SZAKIRODALMI ÁTTEKINTÉS}

A szakirodalomból az identitás és a HR témák kapcsolódnak a vizsgált témához, amely a területiség és a sport kapcsolatában mutatja be az identitást. Az alábbiakban ezek legfontosabb vonatkozásait emeljük ki. Az identitás mintázatoknál egy szélesebb témakört a területi tőke és a területi identitás jelentőségét ismertetjük, valamint annak kapcsolatát a sportolói identitással. A területi tőke identitással való összefüggésének, a területi-, társadalmi-, humán tőke értéknövelésében van szerepe. A sport hatással van a társadalmi folyamatokra, amely mozgatja a gazdaságot, az életszínvonal növekedéséhez járul hozzá, amely a területi versenyképességet növeli. A sportolói identitás szakirodalmi felosztásában számos tényező kerül vizsgálatra, amely kiterjed a sport szempontjából az eredményidentitásra, integráció-identitásra, népszerű identitásra, nemi identitásra, és a regionális identitásra. Az identitásmintázatok a sport területén a külső hatásoknál, a társadalom részéről jelenik meg. Az identitás tényezők bemutatásában a sport és a területi kötődés összefüggései kerültek vizsgálatra az elméleti áttekintésben.

\section{Az identitások sporthoz kapcsolódó aspektusai}

A területi tőke vonatkozásában lényeges komponens a helyi tehetségek megtartása. Ebben a tekintetben alapvető kérdés, hogy erősödik-e a kötődés, a csoportazonosság- 
tudat, a területi identitás (az összetartozás érzése, amelyet a területileg egy helyen élő emberek egymás és az adott terület iránt éreznek, és az adott térséghez kötnek) egy adott térség fejlődésével, és miként hat az ott élő fiatalok karrieresélyeire. A nemzeti identitást egyrészről jellemzi a nemzetközi kép az adott nemzetről és az állampolgárok országról alkotott képe. (Rusciano, 2003) A területi identitás az állampolgárok kötődését, nemzeti tudatát közvetíti, de gazdasági, versenyképességnövelő tényezőként szintén lényeges a nemzetközi megítélés. A lokális közösségi térben kialakult viszonyok determinálják az identitás erősségét, hiszen a közösségi identitás érzése nélkül nincsen területi identitás sem. A bizalom és részvétel faktorai kifejezik a területi identitás erősségét. A területi identitás szintjét jelzi erőteljesebb bizalmunk egy területen élők iránt. A területi identitás mértékét mutatja a közösségben (közeseményeken) való tevékenység mértéke, ami minél magasabb, annál nagyobb a területi identitásunk. A területi tőke vonatkozásában meghatározó a siker, amely identitásnövelő tényező. Amely terület közössége, gazdasága sikeres, a lakosoknak vonzóvá, követendővé, azonosulásra alkalmassá válik. A társadalmi elit kapcsolatában a társadalmi siker különösen függ a fejlettségtől és az elégedettség érzésétől, amely pozitívan hat a területi identitásra. Az elit kiválóan modellezi a területi identitás és a társadalmi siker közötti szoros harmóniát (Bugovics 2010).

„Az egyén társas és társadalmi létezése valamiféle rendezett struktúrát igényel. Ez az egyén pszichológiai szükséglete, hiszen egy kaotikus világban képtelen lenne ésszerūen cselekedni: tehát igyekszik azonosságát (identitását) meghatározni" (Csepeli, 1987, p.143). A sportoló egy rendezett struktúrában tudja tevékenységét végig vinni; sikerének záloga a közösség, a szakmai háttér és a rendezett szervezet megléte. A társadalmi identitás „olyan önmeghatározó kategóriák elfogadását" jelenti, amelyek „révén az egyén a közvetlen személyes tapasztalat világában az emberek nagy csoportjai között helyezi el önmagát az ismerősség és az idegenség dimenziója mentén" (Csepeli, 1987, p.149). A sportolói szempontból az önmeghatározás, az ismerősség-idegenség dilemmái megjelennek, hiszen a sikeres sportoló a közösségének kiemelt tagja. A sportolónak szembesülnie kell sportolói karrierjének, sikerének csúcsán a dilemmával, hogy mihez kötődik: hiszen amikor a sportoló tovább szeretne lépni, sokszor választania kell a helyhez való erős kötődés és a továbblépés lehetősége között (ha például el kell költöznie, mert magasabb szintű csapatban van esélye szerepelni). A sportolói tehetség területi megtartásában nyújthat segítséget az élsportolói életpálya modell, amellyel a régió tehetségmegtartó ereje fokozható.

\section{Sportolói identitás}

A sportolói identitás értelmezésében a sport társadalmi beágyazottságban jelenik meg. Ez nagyon széles körű tér, amely a sport erőteljes mediatizáltságának köszönhető (Dóczi, 2008). A nemzeti identitás és a sport viszonya bemutatásának egyik kézenfekvő modellje Henning Eichber (2003), dán sporttudós tipológiája. Eichberg a nemzeti identitásban a sportot háromféle módon kezeli, amelyek aspektusaikban eltérőek. 
1. Identity of production (eredményidentitás): Jelentősége az olimpiai sportokhoz köthető, ahol a versengés és az eredmény a kulcsfontosságú. A nemzetek életében egy-egy sportsiker a nemzeti identitásban is jelentős szerepet játszik. Például Ausztriában a második világháború után a nemzeti identitás újjáalakításában nagy szerepet képviseltek a labdarúgásban és az alpesi síben szerzett sikerek (Horak, Spitaler, 2003).

2. Identity of integration (integráció-identitás): Az integráció elötérbe kerülése a fó motívuma, amely a közösség sportszervezésében nyilvánul meg. Példaként a világesemények tekinthetőek az integrációs identitás mintáinak. A nagy sportesemények alkalmat adnak arra a nyitó és záró ünnepségen, hogy a rendező ország a nemzeti kultúráját és történelmét bemutassa a világ többi nemzetének.

3. Popular identity (népszerű identitás): A karneváli identitás a népi játékokból, ünnepekből ered, és a közös, fesztelen együttlét érzéséhez köthető. A karneváli identitás azonosítását Richard Giulianotti (1999) a skót futballszurkolók híres csoportja, a Tartan Army esetében azonosította. A területet agresszívan védelmező huligán szubkultúrával ellentétben, a karneváli szubkultúra inkább vidáman ünnepli nemzeti identitását. Ez a „posztmodern" szurkoló-típus ma már uralja a világ nagy sportünnepeinek lelátóit, és közel áll a magyar kézilabda és vízilabda-rajongói szubkultúrához is (Dóczi 2008).

A sportoló sporthoz való kötődése egyértelműnek tekinthető, de a társadalmi-, gazdasági viszonyok miatt nem feltétlenül jelenik meg az ifjúsági sporton kívül, a felnőtt életkor pályaválasztási szakaszaiban, amely a társadalmi tőkét erősíti. Az említett szakirodalmi csoportosítás a társadalom és a sport kapcsolatát mutatja, a sportoló és a sporthoz kötődő viszonyban számos további tényező jelenik meg. A sportolói identitás megjelenése a sportban való civil tevékenységben bontakozik ki, amely az életpálya több területén jelenik meg, mint az életminőség alakítás, a sport támogatás, a sport gazdasági funkcióinak kihasználása, a sport szolgáltatási szektorainak kiterjesztése.

\section{Nemi identitás a sportban és a munkaerópiacon}

A tanulmányban bemutatásra kerülnek az identitásmintázatok, amelyekben lényeges szerepet tölt be a nemi identitás. Legtöbb sportág kétnemű. Az esélyegyenlőség a civil szférában sem minden esetben érvényesül. Ennek alapja, a kutatási eredmények szerint, hogy erős konszenzus van a sporttal kapcsolatos sztereotípiák és nemi szerepek között (Béki, 2017). Az identitások vizsgálatánál a nemi identitás is jelentős társadalmi problémát vet fel, hiszen kérdésként jelenik meg a sportban, hogy kialakul-e a jövőben a sportágaknak egy nemre jellemző változata, vagy a sportágban szereplő sportolók nemi identitása kérdőjeleződik-e meg? (Béki, Keresztesi, 2017) A munkaerőpiacon megjelenő nemi egyenlőtlenségek, az azonos munkaterületeken megjelenő fizetések nemenkénti eltérése, a vezetői pozíciókban mutatkozó különbségek a nők és a férfiak reprezentativitása területén hasonlóságokat mutatnak, amely a nemzetgazdasági 
eredményességre is hatással van. A női szerepek a sportban is megváltoztak, egyre több nő vesz részt a férfiasnak mondott sportágakban, amelyek hatásaként a sztereotípiák a társadalomban formálódnak, elfogadóbbá válnak (Béki, Géczi, 2017). A nemek munkaerőpiaci egyenlőtlensége és a nők és férfiak felemás magánéleti szerepvállalása kölcsönösen összefügg, ezért a megoldás leghatékonyabban egyszerre kezelendő (Vajda, 2014), akár a korábban említett atipikus foglalkoztatás által. Magyarországon a nők férfiakhoz képesti jövedelemhátránya 13-18 százalék között van, amivel nemzetközi összehasonlításban az európai középmezőnybe tartozunk (Vajda, 2014).

\section{Regionális versenyképesség és a HR kapcsolata - regionális identitás}

A sportoló a sportpályafutását követően a munkaerőpiac részeként jelenik meg, mint humán tôke. Ebben a szakaszban érintett a sportoló, a vállalat és a helyi, sportolókkal kapcsolatos irányelvek. A sportolók, mint humán tôke, a regionális versenyképesség tényezői, abban a tekintetben, amikor a sport során kialakult kompetenciák hasznosulhatnak a munkaerőpiacon. A vállalati szféra és a sportoló kapcsolatában az összekötő tényező a területi gazdasági, társadalmi növekedés, amelyben a sportoló értékteremtő funkcióval bír.

Egy régió versenyképességében meghatározó szerepe van a területi tőkének. A területi tőke a területrendszerben rendelkezésre álló s felhalmozott gazdasági, társadalmi és kulturális tôkék közös felülete, amelyek az adott helyre jellemző, és csak az adott időben és helyszínen jelenik meg (Rechnitzer, 2016). A területi tőke fogalmát és elméletének alapjait Camagni $(2008,2009)$ teremtette meg. Modellje a tőkejavak és a „hard” és a „soft” tényezők mátrixa. A modell megkülönböztet formális és informális folyamatokat. Formális szinten a hely pozicionálása, elhelyezkedése, a róla kialakult vélemények és vonzása (tőke-javak, munkaerő, tudás, innováció) fogalmazódik meg. Kiemelten fontosak az esetleges klaszterek, hálózatok, a civil szféra, avagy a lokális társadalom terei. A sikeres régió területi tőkéje gazdasági, társadalmi és kulturális elemeket tartalmaz. A vállalatok és a régió versenyképességében a társadalmi tőke részeként jelenik meg a humán tőke. A humán erőforrás területi elemzésében a fejlődést hordozó erőforrás tényezőiként és hatásmechanizmusának lényegi elemeként jelenik meg az emberi tényező, az életminőség, az életkörülmények, a tudás, az ismeretközlés és -átadás hálózata, és a települési innovációs miliő (Rechnitzer, 2007). A sportoló, mint humán tőke jelenik meg ebben a folyamatban, hiszen az életminőség javításában, a sportolói sikerek, a nemzeti, területi identitásban, mint humán tényező aktivizálja értékeit. A sport, az életmód, életszínvonal alakításban a fizikai aktivitás szerepe kiemelt (Szakály és mtsai., 2016), amelynek meghatározó képviselője a sportoló.

Az alábbi ábrán válik láthatóvá, hogy kapcsolódik a sportoló a regionális identitáshoz (1.ábra). A sportoló, mint társadalmi tőke jelenik meg, amely nem csak a sportolói eredményességben nyilvánul meg, hanem az élsport utáni életszakaszban is, amikor a sportoló a humán tôke elemeként jelenik meg. Itt fontos szerepe van a régió (az itt működő vállalatok) tehetségmegtartó erejének. A vállalatok a tehetséget, a humán tőke 
erősítéseként a sportolói bázisból meríthetik, amelyben a sportoló a regionális identitás erősítő funkcióját látja el (Palkó, 2011). A regionális identitásban a vállalatok a funkcionális identitást képviselik, amely a gazdasági, társadalmi hatás összekapcsolását jelenti (Lukovics, 2004). Korábban bemutatásra került a regionális identitás versenyképesség növelő tényezője, amelyben a sportoló már mint humán tőke jelenik meg. A vállalatok részéről a sikert a sikeres sportoló is szimbolizálja, amely imázsépítő funkcióval bír a vállalati kommunikációban (Gyömörei, Tóth, 2012).

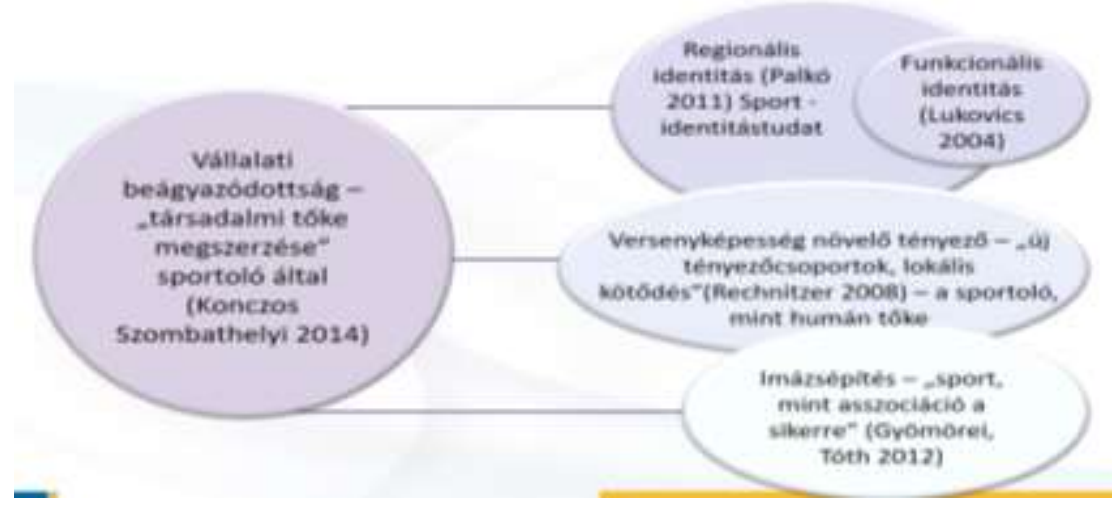

\section{1. ábra. Sportolói regionális identitás modelljeinek rendszere}

Forrás: Saját szerkesz̧tés

\section{Tehetségmenedzsment a HR és a sport területén, a területi töke elemeként}

A regionális tehetségmegtartó erő a területiségben meghatározó a társadalmi- és humán tőke elemeként. A tehetség a területiségben identitásnövelő funkcióval bír, mint az egy területen élők sikerrel való azonosulása (Bugovics, 2010). A sport ebben jelenik meg identitásnövelő elemként, hiszen a sportolói tehetség a pályafutása alatti sportsikereit az adott térhez társítja, majd a humán tőkét erősíti a munkaerő-piacon, és a sportolói kompetenciáit beépítve más pályán megjelenő munkaerő. A munkaerő-piacon a tehetség a humán tőke erősítésében kap szerepet. Kérdés, hogy a sportolói tehetség a munkaerőpiacon is tehetség-e? A tehetséggel való azonosulás egy területen élők részéről identitásnövelő tényező. A tehetség-összetevőket nem készen kapjuk születésünkkor, hanem ezek hosszas fejlesztő munka eredményeként formálódhatnak (Konczosné Szombathelyi, 2013). A vállalatok stratégiájának lényeges eleme a tehetséges munkaerőnek a céghez vonzása, megfelelő feladatokkal ellátása, továbbfejlesztése, az egyéni és a vállalati célok összehangolásával a munkaerő megtartása. Mindez az egyéni, a vállalati és a társadalmi érdeket szolgálja, és kifejezheti a vállalatok felelősségvállalását a hozzájuk került tehetségek iránt. A tehetségekkel való felelős foglalkozás nem csupán a HR részleg feladata, de a vállalati stratégia része kell, hogy legyen (Konczosné Szombathelyi, 2014). A sportolói tehetség a vállalatok számára is meghatározó húzóerőt jelenthet, amennyiben a HR stratégiájukban is számba veszik és érvényesítik a vállalati tehetségmenedzsment területén. 
A sportolói oldalról az élsport végeztével a sportolók kezét elengedik, és a munkaerőpiacon való érvényesülésük nehézségekbe ütközik. Ezt a problémát az amerikai kontinensen hosszú évek óta kezelik, Európában még csak az Európai Unió általi ajánlások, kezdeti lépések történtek meg. A probléma megoldására láthatóvá szükséges tenni, melyek azok az elemek, amelyek külső és belső tényezőként hatnak a sportoló pályafutására, és milyen fejlesztési megoldások válhatnak be e probléma megoldására (Faragó et al., 2018). A sportolói tehetség, a sportolói életútprogram megalapozza a sportolói karrier további útjait a civil életben (Faragó, 2015). A sport tovább erősíti a képességeket, és új képességekkel ruházza fel a fiatalokat. Ezek az értékek azok, amelyek a munkaerőpiacon a humán képességek közé sorolhatók, és egyre nagyobb jelentőséggel bírnak a munka világában is (Faragó, Konczosné Szombathelyi, 2017).

\section{ANYAG ÉS MÓDSZER}

A kutatás célja azon elemek feltárása - a sportoló, a vállalat és a helyi sportgazdaság összekapcsolódásának vizsgálatában -, amelyek hozzásegítik a sportolókat a munkaerőpiaci érvényesüléshez, a vállalatokat a humán tôke erősítéséhez, a régiót a tehetségmegtartó erejének a növeléséhez. A vizsgálat lényegi irányvonala a sportolók identitása, a sporthoz való kötődése a pályaválasztás tekintetében. A szakirodalmi identitásminták szekunder kutatása mellett online kérdőíves kutatást végeztünk a sportolók között annak feltárására, hogy mennyire erős az identitásuk a sporthoz, a sportolói karrierjük végeztével milyen szándékaik vannak a sportban maradásra. A kutatás mintája 14 év feletti, sportegyesületben sportoló személyek, valamint, akik korábban sportoltak versenyrendszerben. A vizsgálat online felméréssel történt, amelynek előnye, hogy nincs kérdezőbiztosi torzítás. A kitöltéshez országos eloszlásban sportegyesületeket kértünk fel, hogy töltessék ki a kérdőívet. Az eredmény nem reprezentatív, az alacsony elemszám miatt. Az eredmények 174 válaszadó alapján kerültek értékelésre. A kérdőív kérdései a sportban szocializált személyek sporthoz való kötődését mérte fel, amely a sportolói élet utáni pályaorientációt is vizsgálta. A kutatási kérdések kiterjedtek a továbbtanulási szándékra: a sporthoz kötődik-e vagy más irányt képvisel? A sportszférában szeretne-e maradni a tanulmányok végeztével? Az eredményeket SPSS statisztikai program segítségével elemeztük, amelyben a leíró statisztika és kereszttábla elemzések kerültek előtérbe.

\section{EREDMÉNYEK}

A kutatási kérdőív feldolgozását, bemutatását a tanulmány témakörének megfelelően ismertetjük. Az eredmények leglényegesebbnek ítélt válaszait ábrákon is szemléltetjük. A felmérés országosan vizsgálta a sportolókat az identitásukra vonatkozó kérdések alapján. A válaszadók $(\mathrm{N}=174)$ nemenkénti eloszlása közel egyenlő arányt mutatott $(51,7 \%$ nő, 48, 3\% férfi). Az adatfelvétel alapján Győr-Moson-Sopron megyéből töltötték ki legtöbben $(33,9 \%)$, majd Csongrád megye (16,1\%) sportolóinak aktivitása látható a kérdőív kitöltésében. Összesen 18 megyéből érkezett válasz a kérdőívre (2. ábra). 


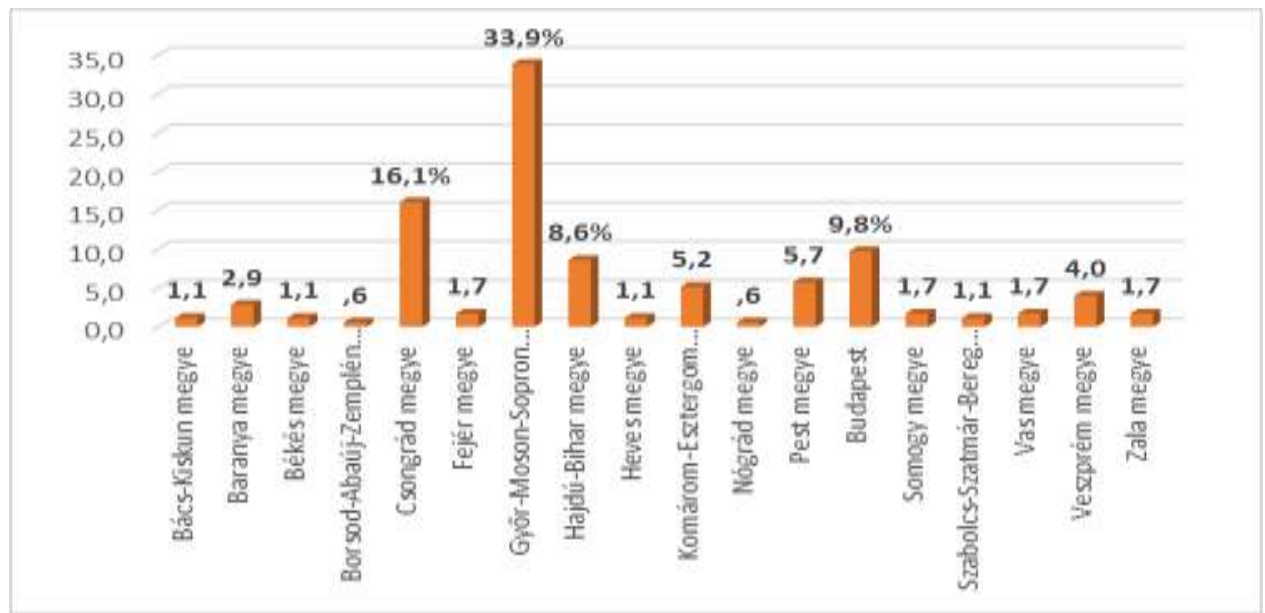

\section{2. ábra. Állandó lakóhelye melyik megyében található?}

Forrás: Saját szerkesztés

A területi megoszlás vizsgálatánál a lakóhely jellegére is rákérdeztünk.. Ebben a tekintetben az előző ábrához köthetően a megyeszékhely $(37,9 \%)$ és a város $(36,8 \%)$ lakosaiból tevődik össze főként a válaszadók lakhelye (3. ábra).

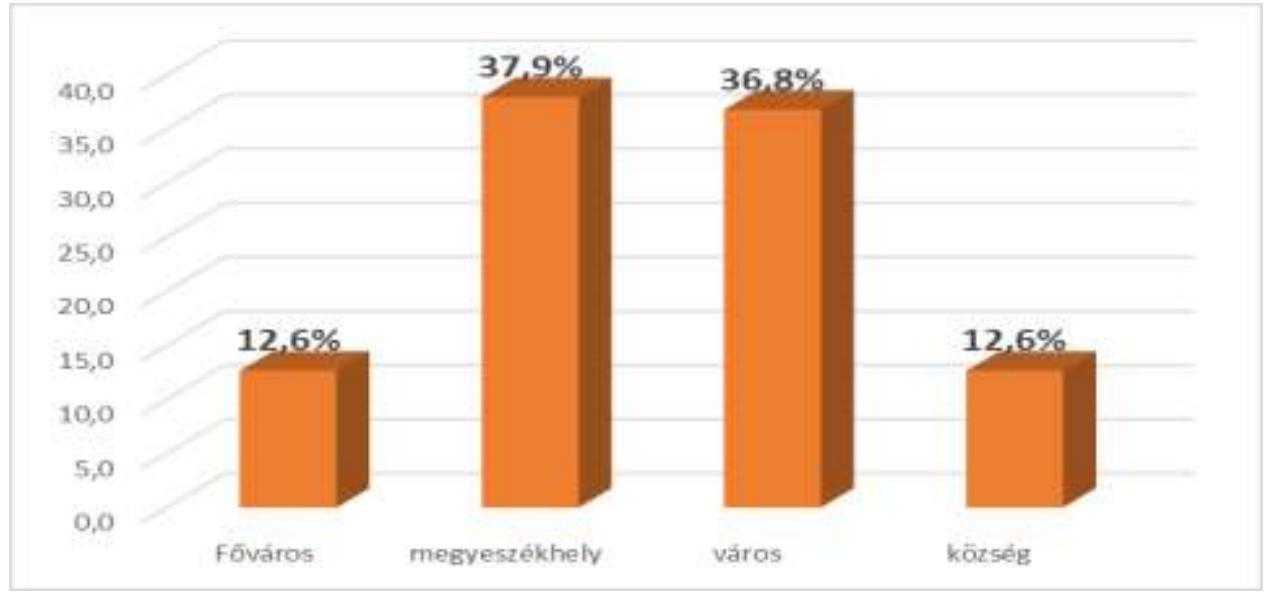

3. ábra. Állandó lakóhelyének jellege

Forrás: Saját szerkesztés 


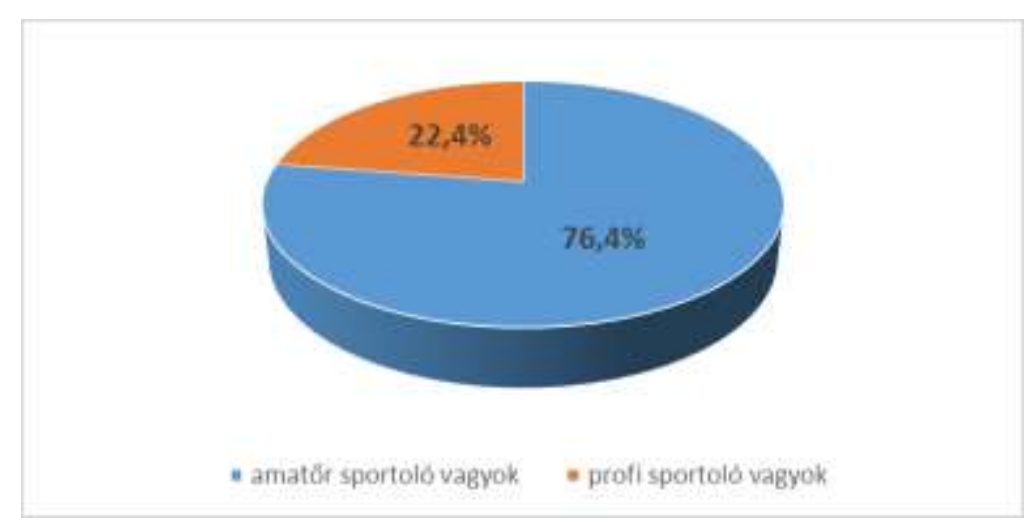

\section{4. ábra. Milyen rendszerben sportol / sportolt?}

Forrás: Saját szerkesztés

A sportolók sportolási rendszere szintén meghatározó a vizsgálat szempontjából. A várakozásnak megfelelően, az amatőr sportolók túlsúlya jellemző (70,7\%), hiszen a lekérdezés a sportegyesületben sportoló 14 év feletti sportolók körében zajlik, amelyben főként amatőr sportolók vesznek részt (4. ábra). A vizsgálat rávilágít arra, hogy a sportágakat tekintve milyen megoszlást mutatnak a válaszadók, a későbbi nagyobb minta alapján esetleges következtetéseket szeretnénk levonni az adatokból. Az elemszám alapján a csapatsportok aránya a nagyobb (64,9\%) (5. ábra).

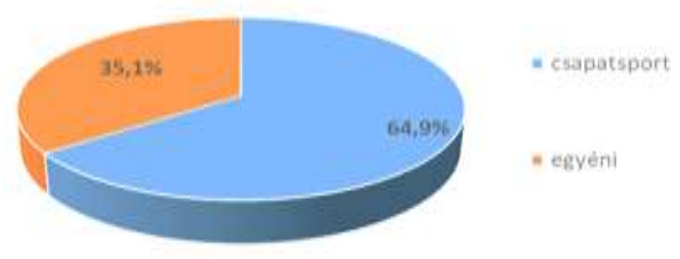

\section{5. ábra. Sportágfajták}

Forrás: Saját szerkesz̧tés

Az identitás vizsgálatában a hagyományoknak, a szülői háttérnek, a szocializációnak jelentős szerepe van. Ezért a felmérésben rákérdeztünk a szülők sportolói múltjára is, amely meglepő eredményt mutatott. A sportolók szüleinek 66,7\%-a nem sportolt versenyszerűen, ennek ellenére fontosnak tartották, hogy gyermekük a sportolói életutat megismerje.

A vizsgálat lényegi kérdésköre a sportolók sporthoz fűződő kapcsolata, annak erőssége. Ebben a kérdéskörben jelentős megtudni, hogy miként tervezik, tervezték a sportolói pályafutásuk utáni életpályájukat. A felmérés megmutatta, hogy akik még nem dolgoznak, azok szakmai tanulmányokban látják a jövőt (33,9\%) (6. ábra). 


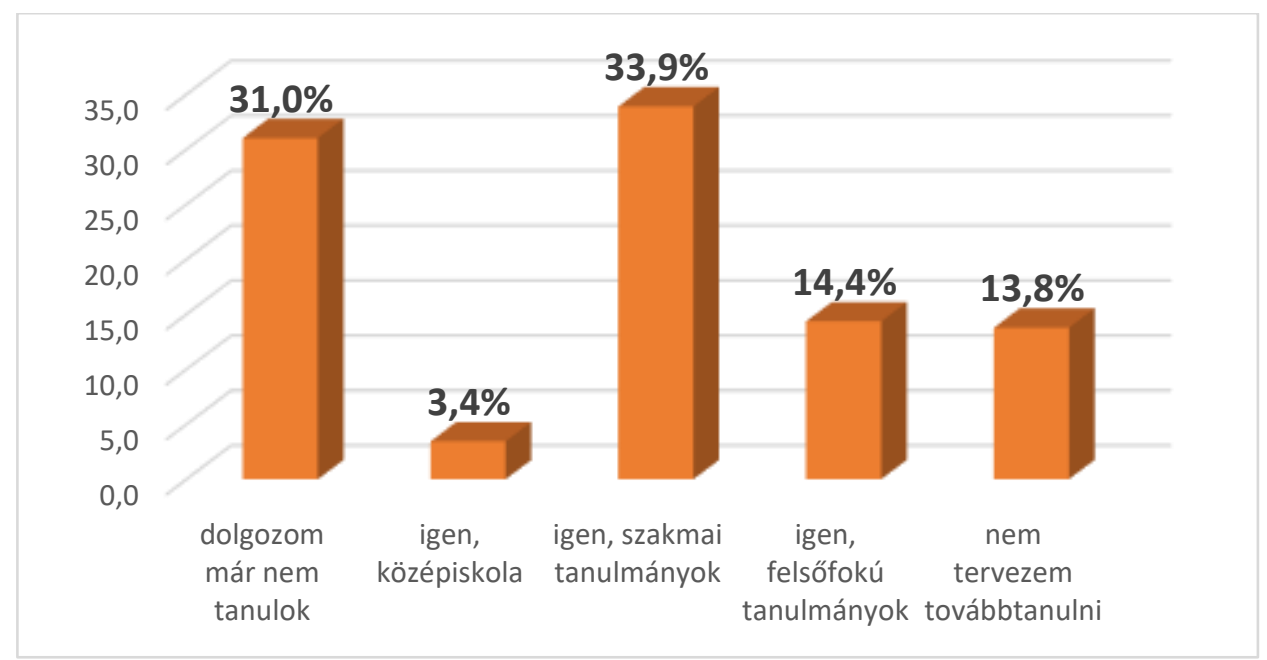

6. ábra. Amennyiben még tanul, tervezi-e a továbbtanulást? Ha igen, milyen szinten?

Forrás: saját szerkesz̨tés

A vizsgálat egyik lényeges kérdésköre arra irányul, hogy a sportolók a sportolói pályafutásukat követően a sportban szeretnének-e maradni? A 7. ábra válaszai alapján a válaszadók 50,6\%-a sporttal kapcsolatos tanulmányokat szeretne-folytatni, amely jelzi a sportolók identitását a sporthoz, a sporthoz köthető tevékenységekhez a sportolási életszakaszt befejezését követően is.

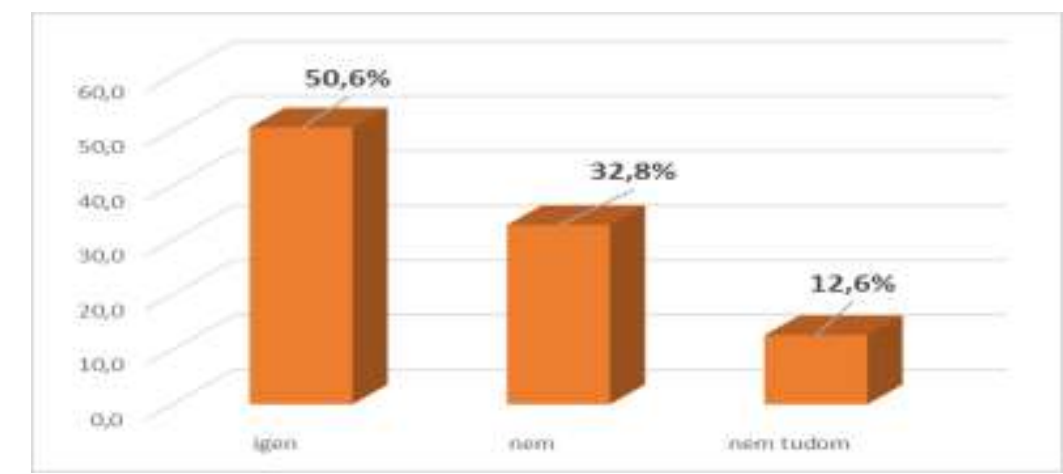

\section{7. ábra. Amennyiben továbbtanul/tanult, azt a sporttal kapcsolatos szakterületen végezné/végezte?}

Forrás: Saját sz̧erkesz̧tés

A sportolói életútban a sportolói identitás kiteljesedésének meghatározója a munka világában való lehetőség, az egzisztencia kialakításának opciója. Amennyiben a sportolónak lehetősége van a sportban tevékenykedni a sportolói karrier után, erősebben megnyilvánul az identitása, hiszen a múltjához kötődő karrierutat tudja folytatni. 
Amennyiben létezik helyi/regionális életpályamodell, az elősegíti a régió tehetségmegtartó erejének növelését, a sporttehetség régióban tartását, annak humán tőke hasznosítását. A sportolói életpályamodellel, az abban jelentkező mentorálással, támogatással a sportoló regionális identitása is megnövekedik. A kérdéskör ebben a tekintetben lényeges, a sportolók az identitásukat megőrzik-e, kötődésük milyen mértékú az életvitelük helyszínén? A helyi önkormányzati vagy szervezeti támogatás befolyásának kérdésköre jelenik meg a kérdőív ezen kérdésében. A válaszadók 49,3\%-a maradna a jelenlegi lakóhelyén, amennyiben érezné a helyi támogatást, de jelentős (41\%) azoknak a válaszadóknak az aránya is, akik mérlegelik a lehetőségeket, és nem feltétlenül ragaszkodnak a jelenlegi lakóhelyükhöz. Kérdés az, hogy ezt a választ az elemszám alacsony mértéke okozza vagy a minta emelkedésével ez az arány növekedhet? (8. ábra)

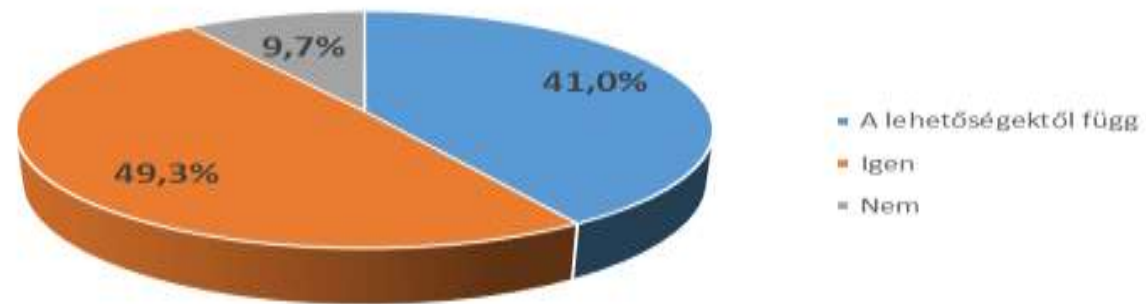

\section{8. ábra. Amennyiben a lakóhelyén sportolói életpályához támogatást kapna, maradna a jelenlegi lakóhelyén életvitelszerűen?}

Forrás: Saját szerkesztés

A következő kérdés a sportolói identitásra kérdez rá: a sportban szeretne-e maradni, illetve a sportban tevékenykedik-e. A felmérésben a kérdőív egyszerre méri fel a jelenleg sportolókat és az élsportot már befejezett személyeket.

A válaszadók jelentős része (50,8\%) teljes mértékben a sport területén szeretne maradni vagy jelenleg is abban dolgozik. Még az eggyel kisebb szintű fokozatot is jelentős számban jelölték meg, „nagyjából egyetértek” (22\%), ami magas szinten képviseli a sportolói identitás jelenlétét (9. ábra). 


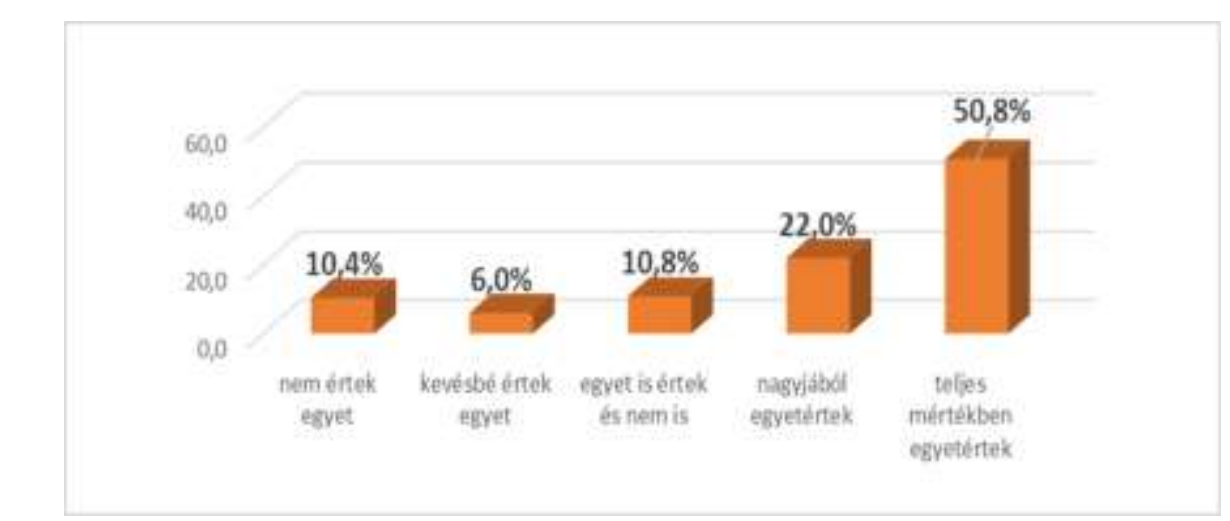

\section{9. ábra. Mennyire ért egyet az alábbi állítással? A sportban szeretnék maradni (edző, sporttisztviselő, stb.)/a sportban tevékenykedem}

Forrás: saját szerkesz̨tés

Lényegesnek tartottuk a kérdéskör ellenőrzését, annak válaszának megerősítését, hiszen fontos a témakör szempontjából, a sportolói aspektus megismeréséből. A kérdés megtámogatására egy fordított kérdést tettünk fel, amely megerősíti az előző választ. „Mennyire ért egyet az alábbi állítással és milyen mértékben? Sporton kívüli munkakört választok, választottam.”, nagyobb szórás látható a skálán. A „nem értek egyet” választ a válaszadók 30,3\%-a jelölte meg, míg a „teljes mértékben egyetértek” alacsony arányt képvisel. Az eredmény arra enged következtetni, hogy a sportolók szívesebben választanak sporthoz kötődő tevékenységet, hiszen a sporthoz való kötődésük erős mértékű, amely az előző kérdéssel egyező választ adott (10. ábra)

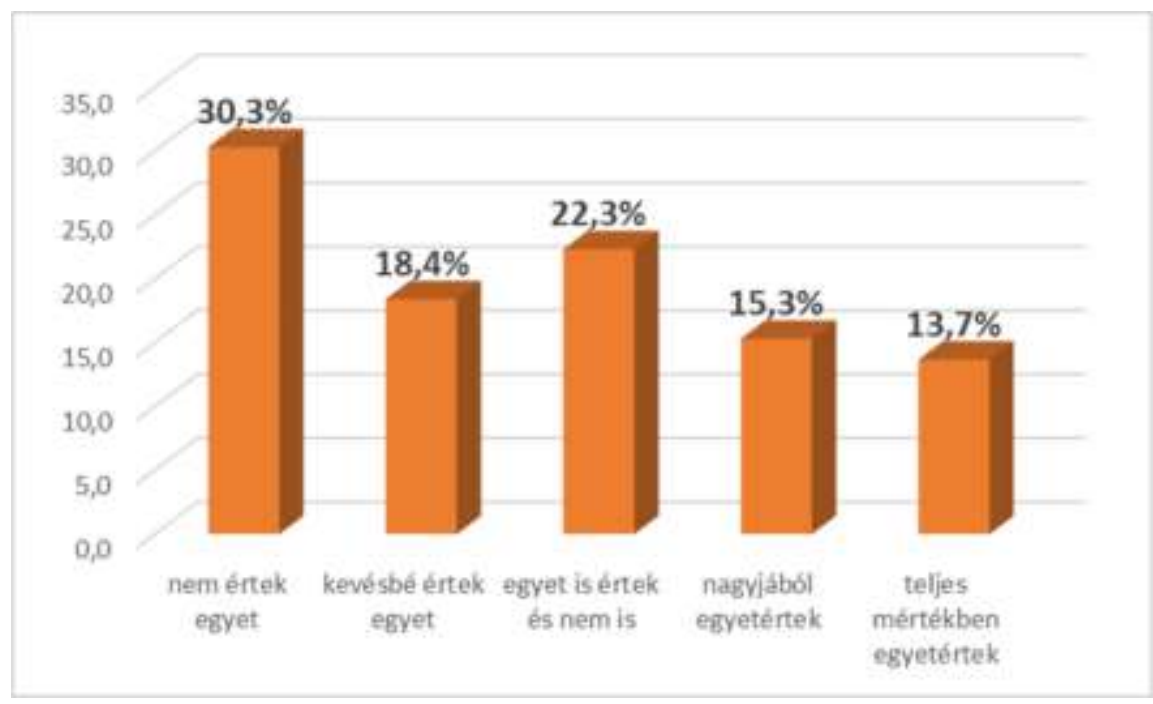

10. ábra. Sporton kívüli munkakört választok / választottam

Forrás: saját szerkesztés 
Az eredmények alapján megerösitést nyert az első hipotézis, miszerint a sportolók a sportolói pályafutásukat követően a sporthoz jelentősen kötődnek, ezzel a sport funkcióinak társadalmi-, gazdasági hatásait lokális szinten erősítik.

Szintén igazolódott a második hipotézis, miszerint a megkérdezettek többsége a sportolói pályafutását követően a sportban szeretne maradni. A sportban szocializált személyek számára a sportolói identitás megjelenik a civil szférában is, a munkaerőpiacon és a munkavállalói oldalon is.

A sikeres régió területi tőkéje a társadalmi, kulturális javak összességéből tevődik össze, amelynek része a humán erőforrás. A fejlődést hozó erőforrás az életminőség, az életkörülmények, a tudás (Rechnitzer, 2007), amelyben a sportoló és az életminőség növelésében segítő szakember a versenyképességet növelő tényezőként van jelen. A társadalmi tőke elemeként megjelenő sportolók, a civil pályán is a területi tôkét erôsítik a társadalmi tevékenységükkel (egészségnevelés, sportszocializáció, nemzeti identitás).

A harmadik hipotézis is igazolva látszik, miszerint a sportolók tanulmányaikat sport területén szeretnék végezni, amely a területi tőke növeléséhez járul hozzá. A sportoló válaszadók irányultsága erősen a sportszakmai tanulmányok felé mutat. A sport területén tanulmányokat folytató későbbi szakemberek a lokális társadalmi életminőség fokozásában, a sporttehetségek helyi gondozásában, az oktatási bázis erôsítésében jelentenek értéket. A tudás, mint tőkeelem, annak lokális megjelenése a sportgazdasági szektor növekedését eredményezi.

\section{KÖVETKEZTETÉSEK, JAVASLATOK}

A területi tőke identitás faktorának erősítése a sportolói identitás által A tanulmányunkban az identitás területi, sportolói dimenzióit vázoltuk fel. Az első részben az identitás sporthoz köthető tényezőit mutattuk be, amelyek a pályaválasztás, sportolói karrierút részeként jelennek meg. Az identitás elméleti hátterében összefüggés tapasztalható a sport, mint örökség, mint kötődés tényezője és a nemzeti identitás meghatározó attitűdjei között. A szakirodalmak alapján láthatóvá vált, hogy a sport a nemzeti identitást befolyásoló tényező, amely a területiségre is hatással bír. A regionális identitásban a lokális társadalmi mozgások is formálják a beavatkozást, amely jelenti a gazdasági szereplők beágyazódásának, identitási törekvéseinek eszközét, ez akár a sport által, mint szponzoráció, sportinfrastruktúra fejlesztés, a helyi kulturális tőkéhez való hozzájárulás. A regionális identitás tényezője a siker, amely a sportban is kiemelt szerepet képvisel. A helyi sportsikerek növelik az identitást, amely a társadalmi tőkét is erősíti területi szinten. Ezek összhangja, egymást erősítő szerepe, egymásra hatásai jelentik a regionális identitás mértékét. A sport és a sportoló megjelenése a sportolói sikerekkel kezdődik, de az életpálya nem ér véget, a sportoló identitásában mindig sportoló marad és az tehetségét helyi szinten kamatoztatja. Az identitásmintázatokban megjelenő tőke elemek a sport és a sportoló vonatkozásában is megjelenik az adott terület társadalmi-, gazdasági növekedése tekintetében. 
A tanulmány második részében a primer kutatásunk a sportolói identitást vizsgálta. A sportolói identitás erőssége a felmérés alapján igazolást nyert, a sportolók kötődése a sporthoz több területen nyilvánul meg. Egyik rész a tanulmányok: a sportolók többsége a sport területét jelölte meg, érdeklődése és kötődése ezen a részen is megmutatkozik. A másik terület a munka világa. Gyermekként a sportban való szocializáció nem csak a kompetenciákat, a fizikai és szellemi képességek fejlesztését teszi lehetővé, hanem egyfajta kötődést is, ami a sportolói identitást határozza meg. Ez kihat a tanulmányokra, ahogy az előzőekben említettem és megjelenik az életpályán is a civil életben. A sportoló kötődése, sportolói identitása a munkaerőpiacon is a sporthoz köti, szeretne ezen a területen érvényesülni, kötődése alapján. Ez természetesen mindenkinek nem lehetséges, az életutak különbözőek, de az identitása alapján a sporthoz valamilyen formában kötődni fog. Ez megnyilvánulhat a szponzorációban, a sportközvetítések nézésében, a sportversenyek látogatójaként vagy a gyermeke életútjának terelgetésében. A területi tôke elemei, mint a társadalmi tőke, humán tőke a sportoló vonatkozásában is megnyilvánulnak. A sportolói identitás megjelenik a sporthoz füződő viszonyban, amely a területhez köti, amelyben a társadalmi tőkét erősíti a sportolói sikereivel, a sport, mint kultúra képviseletével, majd a civil pályán a munkaerő-piacon a szakember bázis növelésével, a nemzeti identitás, a nemzetgazdaság növelését eredményezve.

\section{KÖSZÖNETNYILVÁNÍTÁS}

A tanulmány a "Nemzetköziesítés, oktatói, kutatói és hallgatói utánpótlás megteremtése, a tudás és technológiai transzfer fejlesztése, mint az intelligens szakosodás eszközei a Széchenyi István Egyetemen" címú (azonosító szám: EFOP-3.6.1-16-2016-00017) projekt keretében készült.

\section{FELHASZNÁLT IRODALOM}

Béki Piroska, Keresztesi Katalin (2017) A sportok királynője női szemmel. Agrártudományi Közlemények/ Acta Agraria Debreceniensis (72) pp. 25-32.

Béki Piroska (2017) Sztereotípiák a sportban, avagy a női sport létjogosultsága napjaink magyar társadalmában. Acta Academiae Paedagogicae Agriensis Nova Series: Sectio Sport 44: pp. 171-189.

Béki Piroska, GÉCZI Gábor (2017) Women on ice - gender equalization. Apstract - Applied Studies In Agribusiness And Commerce 11:(1-2) pp. 137-145. (2017)

Bugovics Zoltán (2010) Az elitidentiás háttere. Tér és Társadalom 24. évf. 2010/2. 17-29. p., Tér és Társadalom, XXIV. évf. 2: 17-29

Camagni Roberto (2008) Regional competitiveness. Towards a concept of territorial capital. In: Capello, R. - Camagni, R. - Chizzolini, B. - Fratesi, U. (szerk.): Modelling regional scenarios for the enlarged Europe. Springer, Heidelberg, pp. 33-46.

Camagni Roberto (2009) Territorial capital and regional development. In: Capello, R. - Nijkamp, P. (szerk.): Handbook of regional growth and development theories. Edward Elgar, Cheltenham, Northampton, pp. 118-132. 
Csepeli György (1987) Csoporttudat — Nemæęttudat. Magvető Könyvkiadó, Budapest.143 p., 149.p.

DÓCZI Tamás (2008) Magyar sport és nemzeti identitás a globális sportszíntéren. Magyar Sporttudományi Szemle. 9. évf., 36. 2008/4. 3-7.p.

Eichberg Henning (2003) Playing and Displaying Identity - About Bodily Movement, Political Ideologies and the Question of Olympic Humanism. In: Pawlucki, A. (szerk.): Postmodernity and Olympism. Academy of Physical Education and Sport, Gdansk, 57-78.

Faragó Beatrix, Béki Piroska, Konczosné Szombathelyi Márta (2018) Correlation between athletic and workplace career in the competency matrix. In: Karlovitz János Tibor (szerk.): Some Recent Research from Economics and Business Studies. Komárno: International Research Institute, pp. 73-80.

Faragó Beatrix, Konczosné Szombathelyi Márta (2017) Strength of region's talent retentions: strengths of athletes. In: Karlovitz J. T. (szerk.): Essays in Economics and Business Studies. Komárno: International Research Institute, pp. 113-120.

Faragó Beatrix (2015) Élsportolók életpálya modeljei. Budapest: Campus Kiadó, 2015.

Giulianotti Richard (1999) Hooligans and Carnival Fans: Scottish Football Supporter Cultures. In: Armstrong, G. and Giulianotti, R. (szerk.): Football cultures and identities. Basingstoke; London: Macmillan \& Co. 29-40

Gősi Zsuzsanna, Bukta Zsuzsanna (2019) Sportszövetségek a kiemelt sportágfejlesztés tükrében. Taylor: Gazdálkodás- és Szervezéstudományi folyóirat, A virtuális intézet közép-európa kutatására közleményei 36 pp. 46-55. Paper: 2019/2, 10 p. (2019) https://www.researchgate.net/publication/333702874_SPORTSZOVETSEGEK_A_KIEMEL T_SPORTAGFEJLESZTES_TUKREBEN

Gősi Zsuzsanna, Sallói István (2017) Rögös út a sportkarrier: A fiatal magyar labdarúgók karrieresélyei. Magyar Sporttudományi Szemle 18:(4 (72)) pp. 11-19. (2017)

Gősi Zsuzsanna (2017) Atipikus foglalkoztatási formák sportszervezeteknél. Köztes Európa: Társadalomtudományi Folyóirat: A Vikek Közleményei 9:(1-2) pp. 137-145. (2017)

Gősi Zsuzsanna (2018) Magyarországi iskolarendszer alapú sporttámogatások. Sport, tanulás, karrier. Neveléstudomány: Oktatás Kutatás Innováció (2) pp. 44-60. (2018)

Gyömörei Tamás, Tóth Barbara (2012) A sport piaci értéke. Győri vállalatok szponzorációs hajlandóságának vizsgálata. Magyar Sporttudományi Szemle, 13. évfolyam 51. szám, 2012/3

Horak Robert, Spitaler Georg (2003) Sport Space and National Identity. Soccer and Skiing as Formative Forces: On the Austrian Example. American Behavioral Scientist, 46: 11. 1506-1518.

Konczosné Szombathelyi Márta (2013) Tehetségmenedzsment, avagy a HR felelőssége. In: Róbert P. (szerk.): Gazdaság és morál: tiszta társadalom, tiszta gąđdaság. Győr: Széchenyi István Egyetem Kautz Gyula Gazdaságtudományi Kar, Paper 11.

Konczosné Szombathelyi Márta (2014) Tehetség- és motivációs modell kidolgozásának kérdései a Tudományos és Művészeti Diákkör kapcsán. In: Mészáros A. (szerk.): A felsőoktatás tudományos, módsžertani és munkaeröpiaci kibivásai a XXI. sqaázadban. Győr: Széchenyi István Egyetem, pp. 68-81. 
Lukovics Miklós (2004) A regionális identitás szerepe a regionális gazdaságfejlesztésben. In: Czagány L. - Garai L. (szerk.): A szociális identitás, az információ és a piac. JATEPress, Szeged, p. 214228.

Palkó Katalin (2011) Azidentitás területi dimenzioi a politika tükrében. Doktori értekezés, Pécs

Rechnitzer János (2007) A regionális fejlődés új hajtótényezője a tudás. In: Hervainé Szabó Gy. Szirmai V. (szerk.): Versenyképesség és várostérségi egyenlötlenségek: Tanulmánykötet: A várostérségi egyenlőtlenségek Európában, megújulási válság és leküzdése című konferencia anyagai alapján. 274 p. Komárom, Magyarország, 2006.04.28 Székesfehérvár: Kodolányi János Főiskola; MTA Veszprémi Területi Bizottság; MTA Szociológiai Kutatóintézet, pp. 33-44.

Rechnitzer János (2016) A terïleti tóke a városfejlődésben: A Gyớr-kód. Budapest; Pécs: Dialóg Campus Kiadó, 270 p. (Studia regionum; Dialóg Campus szakkönyvek), 25 p.

Rusciano Frank Louis (2003) The Construction of National Identity: A 23-Nation Study, Political Research Quarterly, Vol. 56, No. 3 (Sep., 2003), pp. 361-366, Published by: Sage Publications, Inc. on behalf of the University of Utah, DOI: $10.2307 / 3219795$

Szakály Zsolt; Liszkai Zsuzsanna; Lengvári Balázs; Jankov István; Bognár József; Fügedi Balázs (2016) Physique, Body Composition and Aerobic Performance of Male Teacher Education Students. Studia Universitatis Babes-Bolyai Educatio Artis Gymnasticae 61 : 2, June pp. 59-71. , 13 p.

Vajda Róza (2014) Munkaerôpiac, foglalkoztatás, vállalkozónők. A nők teljes értékú munkavállalásának akadályairól és esélyeiről. In: A nőtlen évek ára. Magyar Nối Érdekérvényesitó Szövetség, Budapest, pp. 99-151. ISBN 978-963-08-8911-7 
ISSN 2630-886X

18 国 57
BGE 